1 Wulff HR, Anderson B, Brandenhoff P, Guttler F. What do doctors know about statistics? Stat Med 1987;6:3-10.

Berwick DM, Fineberg HV, Weinstein MC. When doctors meet numbers. Am $\mathcal{f}$ Med 1981;71:991-8.

3 Cassells W, Schoenberger A, Grayboys TB. Interpretation by physicians of clinical laboratory skills. N Engl I Med 1978;299:999-1001.

4 Krall JM, Hall DS, Garland BK, Pearson RJ. Physicians' view of the teaching and utility of courses in epidemiology and biostatistics. $\mathcal{F}$ Med Educ 1983;58:815-7.

5 Holy Bible. Gospel according to St Matthew vii, 1-5.

6 Colditz GA, Emerson JD. The statistical content of published medical research: some implications for biomedical education. Med Educ 1985;19:248-55.

General Medical Council. Recommendations as to basic medical education. London: General Medical Council, 1967.

8 Clayden $\mathrm{AD}$, ed. The teaching of medical statistics at undergraduate and post-graduate levels. Leeds: University of Leeds. (Available from Department of Community Medicine.)

9 Langman MJS. Towards estimation and confidence intervals. Br Med 7 1986;292:716.

10 Gardner MJ, Altman DG. Confidence intervals rather than $p$ values: estimation rather than hypothesis testing. Br Med f 1986;292:746-50.

\section{Hypochondriasis: an acceptable diagnosis?}

Can a persistent belief in a non-existent illness be an illness itself? Hypochondriacal fears and feelings are well recognised features of depression, ${ }^{1}$ but doctors disagree over the existence of a neurotic syndrome of fear of and preoccupation with disease unaccompanied by a more fundamental psychiatric disorder. Early writers were sceptical, ${ }^{2}$ and (despite an absence of statistical analysis and in apparent defiance of its own data) one influential study concluded that an underlying depression would surface sooner or later. ${ }^{3}$

Supporters of the proposal that hypochondriasis is a distinct entity have claimed that the primary condition occurs with only mild disturbance of affect ${ }^{4}$ and is characterised by a prominence of those symptoms-pains, especially in the musculoskeletal system-that are typically hypochondriacal. ${ }^{3}$ From closer examination has emerged a precise descriptive triad of the patient being convinced that he has a disease, fearing the disease, and being preoccupied with his body; this triad arises without underlying affective illness and responds at most temporarily to reassurance. ${ }^{56}$

The debate has, however, been muddied by its emphasis on psychiatric patients, an inevitably biased samplemost of those labelled as hypochondriacs are seen by nonpsychiatrists. But a recent study of medical outpatients has confirmed that the components of the triad correlate not only with each other but also with the number of somatic symptoms, though not the number of established medical diagnoses. ${ }^{7}$ Depression, though often present, is not invariable. Any comment that hypochondriacal beliefs probably lie on a continuum with depression at one end does not diminish the usefulness of the diagnostic category, as, for example, with obsessions. So to view hypochondriacal symptoms as masks of depression is both to undermine the meaning of depression itself and to ignore the mounting evidence.

Despite the lack of supporting information psychiatrists often assume that reassurance is ineffective and that even to consider hypochondriacal complaints encourages further complaining. Thus a belief that such patients should be directed "out of the office as quickly as possible because the time they take up is spent to no good purpose" enjoys unjustifiable popularity. ${ }^{8}$ This negative view probably originates in the absence of physical illness to explain physical symptoms and in the frustration evoked by equally frustrated, possibly antagonistic, patients. It may also reflect a departure from the sick role, which expects the patient to cooperate with his doctor-that is, to accept his word. ${ }^{9}$
But to be effective reassurance must be credible, educative and specific, and directed at both expressed and concealed fears. ${ }^{10}$ Hypochondriacal patients may misinterpret normal sensations ${ }^{11}$ or feel them more sharply. ${ }^{12}$ Childhood experiences $^{13}$ and social reward ${ }^{14}$ may encourage somatic complaints under stress. The scarce research into treatment suggests that such explanation of psychosomatic symptoms coupled with careful examination and reassurance leads to lasting improvements. ${ }^{15}$ Moreover, detailed reassurance becomes increasingly effective over time and can reduce the worries aroused by fresh symptoms. When followed by family counselling on reinforcement ${ }^{16}$ it may be the treatment such patients desperately seek. The sufferer from hypochondriacal neurosis sees perfunctory or ill directed reassurance as dismissal, as failure to take him seriously. $\mathrm{He}$ does not want to be told there is nothing wrong; he needs to understand his symptoms as a first step to overcoming them.

\section{LOUIS APPLEBY}

Clinical Lecturer,

Institute of Psychiatry,

London SE5 8AF

Kreitman N, Sainsbury P, Pearce K, Costain WR. Hypochondriasis and depression in outpatients at a general hospital. Br 7 Psychiatry 1965;111:607-15.

at a general hospital. Brf Psychiatry 1965;111:607-15.

2 Bleuler EP. Textbook of psychiatry. Brill AA, trans. New York: Dover Publication

Kenyon FE. Hypochondriasis: a clinical study. Br f Psychiatry 1964;110:478-88.
Pilowsky I. Primary and secondary hypochondriasis. Acta Psychiatr Scand 1970;46:273-85.

4 Pilowsky I. Primary and secondary hypochondriasis. Acta Psychiatr Scand 1970,

6 American Psychiatric Association Committee on Nomenclature and Statistics. Diagnostic and statistical manual of mental disorders. 3rd ed. Washington, DC: American Psychiatric Association, 1980.

7 Barsky AJ, Wyshak G, Klerman GL. Hypochondriasis: an evaluation of the DSM III criteria in medical outpatients. Arch Gen Psychiatry 1986;43:493-500.

8 Alvarez WC. A gastro-intestinal hypochondriac and some lessons he taught. Gastroenterology 1944;2:265-9.

9 Parsons T. Illness and the role of the physician: a sociological perspective. American foumal of Orthopsychiatry 1951;21:452-60.

10 Kessel N. Reassurance. Lancet 1979;i:1128-33.

11 Mechanic $\mathrm{D}$. Social psychologic factors affecting the presentation of bodily complaints. $\mathrm{N} \mathrm{Englf}$ Med 1972;286:1132-9.

12 Pennebaker JW, Skelton JA. Psychological parameters of physical symptoms. Personality and Social Psychology Bulletin 1978;4:524-30.

13 Parker G, Lipscombe P. The relevance of early parental experiences to adult dependency, hypochondriasis and utilization of primary physicians. Br J Med Psych 1980;53:355-63.

14 Wooley S, Epps B, Blackwell B. Pain tolerance in chronic illness behaviour. Psychosom Med 1975;37:98.

15 Kellner R. Psychotherapeutic strategies in hypochondriasis: a clinical study. Am f Psychother 1982;36:146-57.

16 Barsky AJ, Klerman GL. Overview: hypochondriasis, bodily complaints and somatic styles. Am $\mathcal{F}$ Psychiatry 1983;140:273-83.

\section{Inequalities and the new Health Education Authority}

When our reporter arrived at the Health Education Council last week to attend a press conference on a new report, ${ }^{1}$ she found the press conference coming out to meet her. The report was an update of the Black report on inequalities in health, ${ }^{2}$ and Sir Brian Bailey, chairman of the now defunct Health Education Council and new chairman of its successor, the Health Education Authority, had ordered the press conference to be cancelled. He was apparently annoyed that the council had not had a chance to approve a report that he said was "political dynamite in an election year." Sir Douglas Black, Margaret Whitehead (author of the report), and other distinguished guests were not upset at being thrown out: they knew that any attempt at suppression would guarantee front page coverage-and so it turned out. But this episode raises important issues-in particular what is the future of the new authority and its chairman? 
The new report shows clearly that inequalities in health in Britain are getting worse not better. This will come as no surprise to readers of the $B M F$, and some of the evidence is tellingly summarised by Professor Alwyn Smith on $\mathrm{p} 881$. The report contains no new data but simply reinforces the message of the latest research. Between 1971 and 1981 overall mortality fell in Britain, but non-manual workers experienced a much greater decline than manual workers-and so the gap grew. Among women death rates from coronary heart disease and lung cancer rose in manual groups but fell substantially among non-manual groups. Differences in chronic sickness rates between manual and non-manual groups also widened. There is, however, an exception to the widening gulf between the rich and poor: during the ' 70 s deaths in babies aged 1 month to 1 year fell dramatically, especially in social class $\mathrm{V}$. This narrowing of the gap is important because it shows that inequalities in health are not "inevitable." They can be reduced.

New evidence since the Black report has tended to confirm its conclusions that it is socioeconomic deprivation itself that harms the health of the poor. The inequalities are not a statistical artefact, the new report emphasises, and the tendency of those with poor health to descend the social scale explains only a small fraction of the differences. Poorer people have higher death and sickness rates just because they are poor - and because they are less likely to have a job and more likely to live in poor housing and to have had a poorer education. They do also smoke and drink more, eat poorer diets, and exercise less, but these differences in lifestyle do not account for all the difference in mortality. Furthermore, as new evidence shows, their material deprivation limits their ability to choose healthier lifestyles-healthier diets, for instance, are more expensive. Policies to combat inequalities in health by concentrating on the individual are thus, the report says, "misguided."

The chapter on response to policy recommendations emphasises the view that the government is not taking seriously its commitment to the World Health Organisation to reduce inequalities in health by $25 \%$ by the year 2000 . None of the recommendations of the Black report-even those that would have cost little or nothing - have been taken up; child health services are probably in poorer shape now than they were at the beginning of the decade-as are those for disabled people; largely because of unemployment there has been a huge increase in the number of families homeless or in poverty; the housing stock is deteriorating fast; and national and local coordination among agencies for health, housing, environmental control, transport, food, and agriculture are still unsatisfactory.

Sir Douglas Black and his colleagues remain convinced, however, that the inequalities could be reduced in line with the WHO target. This would mean that in 1999, 20000 lives would be saved in those under pensionable age and the number of chronically sick and disabled would be reduced by 100000 . They say in the foreword to the new report: "On the basis of the latest data from the social and medical sciences these kinds of objectives are, in our judgment, attainable." The report describes how a serious commitment in Finland to reducing inequalities has done just that in little more than 10 years by preferentially allocating resources to "less healthy" parts of the country and by switching building costs from hospitals to health centres. This might have been done in Britain had the Resource Allocation Working Party formula operated in a time of increased spending on the National Health Service; instead, the formula has caused economic disruption in a service struggling to conform to government imposed cost limits. The proportion of the gross national product spent on health has declined in Britain in recent years.

This achievement in Finland contrasts with the report that the number of hungry people in the United States has increased from hardly any in the ' 70 s to 12 million children and eight million adults (9\% of the population) now. ${ }^{3}$ This choice also faces Britain. Does it want the gap in income between the rich and poor to grow ever wider? Or does it want to follow a Nordic pattern of trying to eliminate the differences? Northern Europe (including the Netherlands) has the healthiest population in the world. Britain and the US come well down the league table.

Economic policies in Britain have led to increased unemployment, widened the gap between rich and poor, and reduced public expenditure-and so inevitably widened the health gap. The government has also chosen not to spend the $£ 2$ billion that in 1980 Sir Douglas and his committee thought was needed to reduce inequalities. Even more disturbing, however, has been the inclination to sweep under the carpet reports that detail the effects that present day policies are having on the nation's health. Thus attempts were made to bury the original Black report as well as the Central Policy Review Staff report on alcohol.

In all this the Health Education Council has had a sorry time. The appointment of Mike Daube, probably Britain's pre-eminent health campaigner, to the deputy directorship was blocked; the director, Dr David Player, has been "told off" by civil servants for supporting Action on Alcohol Abuse; and expert advisory committees, such as the National Advisory Council on Nutrition Education, are being disbanded. The latest episode is thus just the last in a long line. True, in any public organisation there is a difficult balance between what should be done by the permanent officials and what by the elected or appointed officers. The council was, however, told in January 1986 that a report on inequalities and health was being commissioned, and the report is a technical summary of evidence, not a policy document. The concept of two nations goes back to at least Disraeli, none of the premises in the Black report have been seriously challenged, and those giving the press conference were hardly wild revolutionaries. (Sir Douglas Black is a former president of both the Royal College of Physicians and the BMA and is currently chairman of the BMA's Board of Science.)

Not surprisingly employees of the Health Education Council have left it in droves. It has to be asked how hard Sir Brian Bailey - a man who has served the community elsewhere with distinction-has resisted government interference with the council. The succession of episodes has done nothing to maintain the confidence of the public or the relevant professions in the council; and the latest is a sorry start to the new authority. In our view Sir Brian should consider his position. The new authority needs a strong and independent chairman just as badly as the BBC.

\section{Editor, $B M \mathcal{F}$}

STEPHEN LOCK

Assistant editor, $B M \mathcal{F}$

RICHARD SMITH

1 Whitehead M. The health divide: inequalities in health in the 1980s. London: Health Education Council, 1987.

2 Department of Health and Social Security. Inequalities in health. London: DHSS, 1980. (Black

3 Brown JL. Hunger in the US. Scientific American 1987;256:(no 2)21-5. 